\title{
E-Learning as a Key for Regional Integration through Countries of MERCOSUR
}

\author{
http://dx.doi.org/ijac.v4i4.1736 \\ Mónica Silvestri \\ CEFIR/Training, Montevideo, Uruguay
}

\begin{abstract}
The Center of training for regional integration (CEFIR, in Spanish) was founded more than 20 years with the firm intention to dedicate efforts on issues of regional integration in the four countries of MERCOSUR.
\end{abstract}

Since 2008 has promoted the creation of a platform for elearning and delivered some courses in blended learning and e-learning mode, for training in regional integration issues.

E-learning has become a transversal theme in the organization and became an efficient instrument for promoting regional integration of the 4 countries of the brick. The heterogeneity of countries, cultures and even languages raised a number of challenges when implementing the e-learning strategy.

Index Terms-E-learning, MERCOSUR, regional integration.

\section{INTRODUCING CEFIR}

The Center of training for regional integration CEFIR, (in Spanish "Centro de Formación para la Integración Regional”) was founded more than 20 years ago with the firm intention to dedicate efforts on issues of regional integration in the four countries of MERCOSUR: Argentina, Brazil, Paraguay and Uruguay. CEFIR is located in Montevideo, Uruguay.

It's main focus is related with training people in regional integration, that could impact on their organizations and environments.

Cefir receives the sponsor of cooperation mainly from Germany (InWEnt, actually GIZ), Spain (AECID) and Canada (Canadian Cooperation).

Since its beginning, Cefir has sponsored many activities: seminars, on site courses and meetings inside the four countries of Mercosur. Its main focus is to develop and train on regional integration issues, covering different topics: training of trainers, renewable energies, gender issues, public policies within the Mercosur.

Since 2008, Cefir has promoted the creation of a platform for e-learning and delivered some courses in Blended learning and E-learning mode, for training in regional integration issues (www.formacioncefir.org) .

Since 2010, "E-learning” has become a transversal theme in the organization and became an efficient instrument for promoting regional integration of the 4 countries of the block.

A special chapter is related with technology, where Uruguay's development in Information Technology places it in a privileged place, due its background of excellent percent of Internet connections across the country and the impact of the OLPC project (that provides one laptop in each home).

From this experience and with more than 400 participants, for the next two years CEFIR plans to create and foster communities of practice and the promotion of a network of alumni of CEFIR, meanwhile keeping on improving its training in e-learning and blended learning mode.

\section{BACKGROUND OF THE PROJECT}

Mercosur (in Spanish "Mercado Común del Sur") means "Southern common market". It was created in 1991 and this year celebrates 20 years of the rising of Mercosur. It's a space were countries can exchange products, services, knowledge and share opportunities and challenges within the region.

Mercosur has passed through many different stages of relationships between the four countries; some periods with good progress and another with no progress at all. In the last three years, Mercosur has reached good agreements in different topics.

For Cefir, this stage is related with the interest to collaborate in promoting real and sustainable relations and foster a real integration,

In this scenario, Cefir plays a strategic role as an organization of reference in the region, on regional integration.

Cefir's training became its main mission in order to provide training and integrate the four countries of Mercosur: Argentina, Brazil, Paraguay and Uruguay.

\section{A. Background of the project}

Until 2008, courses were only delivered as "on site" courses. As it can be deduced, training was constraint by bounded costs and number of participants.

In 2008 and after an intern consulting of Inwent (actually GIZ), concluded the feasibility of implementation of an online learning platform to carry on with a formal training project that could impact in a positive way in the organization, increasing number of participants and countries of the region.

The project began in May 2009 and in that year, Cefir had the challenge to develop and deliver four online courses.

\section{B. Selecting an e-learning environment}

The consultancy concluded that an e-learning platform would be appropriate for the project. The following step was hiring an e-learning expert to carry out the project. 
There were different alternatives considered in the learning management systems (LMS), being some of them opensource and some others licensed. This stage concluded that Moodle would be the most suitable platform to implement: there were successful case studies of online courses developed with Moodle.

In one month the platform was created and customized through an outsourcing service hired for the project.

\section{E-learning and blended learning Mode}

Cefir was agreed to promote and deliver two kinds of courses:

- E-learning courses: it means completely online through Internet.

- Blended learning courses: online through Internet with attendance of one week or less in Cefir's classrooms.

Some courses are available only at E-learning mode and others are available at the two modes. It's important to notice that blended learning courses have a special (and higher) budget assigned, due the associated costs at the "face to face" phase of the course.

\section{COURSES OFFERED}

\section{A. The first course}

The first course was a "blended learning" course: with two weeks of online training, one week in Montevideo and two weeks online. The course is named "Training on Mercosur regional integration" (in Spanish "Capacitación en Integración Regional Mercosur”) .

Actually this course is Cefir's main course, and became its "star course". In 2011 it will be its third edition (one edition per year). It is focused on consolidating the fundamental knowledge and skills of young leaders in the process of integration to be able to influence their fields of action.

\section{B. The courses}

In the first year of the project (2009) Cefir could develop these courses:

- Training on Mercosur regional integration ( elearning and blended learning mode): focused on consolidating the fundamental knowledge and skills of young leaders in the process of integration to be able to influence in their fields of action

- Fundamentals of Intellectual Property (blended learning mode, with one week of attendance in Montevideo in the middle of the course): addressed to decision makers in public and private organizations that deal the topic "intellectual property"

- We all are Mercosur (e-learning mode): open to any person no matter its age or studies, aimed to promote Mercosur citizenship.

- Training on Online Tutoring (e-learning mode): with ex participants of Cefir's courses, to foster a community of tutors to carry on with Cefir's online courses.

- Training in social and solidarity economy (blended learning mode): focused on associations and cooperatives; its relationship and the exchange of products through Mercosur
Each course has its own announcement that clearly indicates the profile of participants, main objectives to pursue, requirements of participation and topics of the course.

\section{The experience in 2010}

Last year, two new courses were added to the list:

- Training to trainers: e-learning mode; addressed to high school teachers from different courses: history, literature, philosophy, biology, math, etc, as a way to incorporate the concept of regional integration in their curricula courses.

- Productive integration: blended learning mode, addressed to businessman and organizations to get in touch with different mechanisms of funding and guidelines to design projects of productive integration

\section{COMMON ISSUES OF COURSES}

\section{A. Technology Requirements}

All courses are required that participants must have a computer with Internet access and must have basic skills on IT: file management through operating system, e-mail skills (compose and attach files), Internet skills (perform searches on websites) .

All courses include at the beginning one week of working with the platform, as a way to get familiarized with it.

\section{B. Instructional design of courses}

Courses duration are between six and eight weeks. Each week has it schedule to organize activities for participants and tutors.

Communications between tutors and participants are mainly conducted by Forums, to allow a reflexive participation.

Synchronous communications are chat and video conferencing, using an external product (Wiz IQ). Due the profile of participants and tutors (non IT sector) some tools like video conferencing are not exploded as it should be.

All resources utilized are provided by Moodle, (except video conferencing)

Evaluation of courses are mainly collaborative tasks , where participants are encouraged to work together with a final project, at the end of the course ( about two weeks). This final project is led by one tutor, and completely online.

Feedback from participants is required at the end of the course, through an online survey.

\section{Participants and Gender}

Profiles of participants are mainly from humanistic and social issues; participants come from: politic science, syndical leaders, sociologists, international relations, and students from these area.

The courses emphasize the participation of young people and women. This quota is noted in all courses: participation of young leaders and women are very important. About $60 \%$ of participants are women and the average age is about 32 years.

Related with the country's participation, in all courses it is required to include an equal quota of participants from 
the four countries. In some courses it is possible to give access to participants from other countries like Chile, Venezuela, Perú , Colombia.

For example for main course "Training on Mercosur Regional Integration" shows a distribution like the one depicted in Figure1.

Every edition of this course has a quota of 25 participants meanwhile on each edition, applications rises to 65 .

Related with language, all courses are delivered in Spanish, but participants are encouraged to speak and exchange on their native language. Excepting Brazil (it's language is Portuguese), all the countries speak Spanish, but similarities of the two languages (Portuguese and Spanish) , allow to participate and understand in both languages.

Courses are free for participants, and a previous selection is made in order to shape the group of participants in each group. The selection verifies that the participant matches with the desired profile of the course.

\section{SOME Results ACHIEVED}

In two years more than 400 participants have been certificated through different courses. More than $20 \%$ of them are participants who took more than one course at Cefir during this period.

Every year about 5 new tutors are incorporated to the different courses as experts, to provide online contents to the courses or as tutors in courses.

With this online training, indirectly Cefir contributes to expand the use of technology in learning and to approach people to the use of technology, decreasing the digital gap.

This result is linked with the convenient situation of Uruguay in the use of information technology, meaning excellent Internet access at homes, public sectors and companies. One special chapter is the OLPC project (one laptop per child) which provides every child of public schools its own computer. These achievements are framed in a strong government policy of development information technology in all sectors of the country

\section{IMPROVEMENTS, CHALLENGES AND NEXT STEPS FOR 2011}

\section{A. Language of Mercosur}

We have considered increasing the materials and contents of courses in Portuguese: Brazil is a big country; if we want to increase the number of participants from Brazil, it is highly recommended to develop materials in Portuguese. There is a huge area from Brazil, specially the north, that people doesn't understand Spanish ; therefore they are "auto-excluded" from the courses.

Spanish and Portuguese have similar words; due Argentina, Paraguay and Uruguay have frontiers with Brazil, in this area it is common to speak in "portugnol" a non formal blended language made of Portuguese and Spanish. Participants of courses are mainly from cities of southern Brazil or in near frontiers.

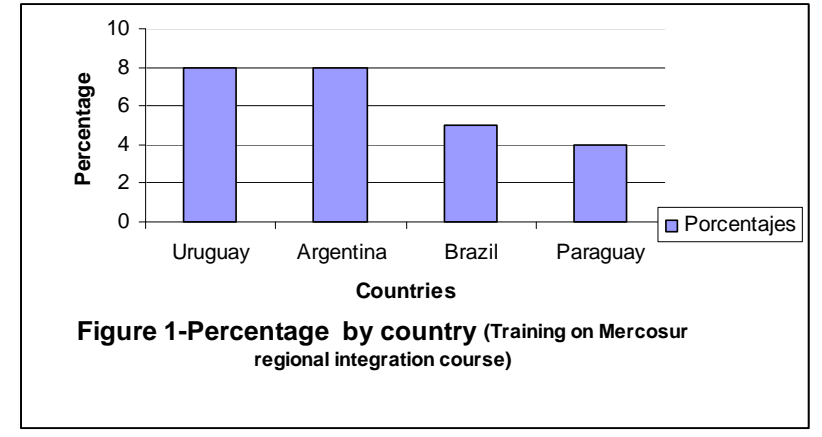

Figure 1.

\section{B. Technology}

The development of Internet is quite similar in Argentina, Brazil and Uruguay. That was an important premise for the project. Paraguay has a different scenario: low access to Internet and computers. These are important constraints for Paraguayan participants that are mainly from Asuncion city (DC). It's imperative to see local options that could allow the access of more participants and from other cities of Paraguay.

At the platform (LMS) and in terms of communications, for 2011 it is proposed to encourage the use of VC with more support for tutors and participants to help them.

The project includes for 2011 the creation and development of an alumni network, as a way to consolidate a community. This will be possible due it has a critical mass of participants to promote this venture.

\section{Participants}

Although there is a quota for participants of each country in all courses, reality shows that applications are mainly from Argentina and Uruguay. It is necessary to increase the number of applications from Paraguay and Brazil: Paraguay due mainly technology issues (as indicated before) and Brazil due language problems.

\section{CONCLUSIONS}

Mercosur is facing a new chapter with opportunities and challenges for all the countries. Information and trained leaders are necessary to carry on with this renewed Mercosur. In this scenario, training is key to giving these leaders the skills and tools to an effective participation in the block, their countries and workplaces.

Opportunities of Internet access and development of technology in these countries of Mercosur, provides the basis for learning enhanced by technology, that perhaps five years ago could not be possible to assume.

In addition e-learning is the only option that provides training facing issues of quantity, quality and equity.

\section{REFERENCES}

[1] G. Caetano, "Los retos de una nueva institucionalidad para el Mercosur”, December 2004.

[2] CEFIR : Centro de Formación para la Integración Regional www.cefir.org.uy

[3] Inwent: Internationale Weiterbildung und Entwicklung

[4] GIZ: Deutsche Gesellschaft für Internationale Zusammenarbeit $\mathrm{GmbH}$ 


\section{AUTHOR}

Mónica Silvestri is with the Centro de Formación para la integración regional (CEFIR), Montevideo Uruguay as Training Coordinator (e-mail: msilvestri@cefir.org.uy).

This article is an extended version from a paper presented at the International Conference ICELW2011, held June 8th-10th, in New York, NY, USA. Received 3 July 2011. Published as resubmitted by the author 15 October 2011. 